\title{
Chemical composition and nutritional value of leaves and pods of Leucaena leucocephala, Prosopis laevigata and Acacia farnesiana in a xerophilous shrubland
}

\author{
Cecilia C. Zapata-Campos', José E. García-Martínez², Jaime Salinas-Chavira1, Juan A. Ascacio-Valdés², \\ Miguel A. Medina-Morales ${ }^{3}$, Miguel Mellado* \\ ${ }^{1}$ Autonomous University of Tamaulipas, Faculty of Veterinary Medicine, Ciudad Victoria, Mexico, ${ }^{2}$ Autonomous Agrarian University Antonio \\ Narro, Department of Animal Nutrition, Saltillo, Mexico, ${ }^{3}$ Autonomous University of Coahuila, Faculty of Chemistry, Saltillo, Mexico
}

\section{A B S T R A C T}

\begin{abstract}
The objective of this study was to determine the nutritional value of three leguminous trees heavily selected by goats in a xerophilous shrubland. Chemical composition and in vitro dry matter disappearance (IVDMD) of leaves and pods from leucaena (Leucaena leucocephala), mesquite (Prosopis laevigata), and huisache (Acacia farnesiana) is presented. Crude protein (CP) ranged from $17.3 \%$ for leaves of huisache to $21.9 \%$ for leucaena. The neutral detergent fiber (NDF) content ranged from 39.0 to 40.3 with no difference among fodder threes. Across tree species, mean IVDMD was $61.6 \%$ for pods and $52.2 \%$ for leaves. IVDMD for leaves was highest $(p<0.01)$ for leucaena $(54.9 \%)$ and lowest for huisache $(47.3 \%)$. Condensed tannins in an acetonic extract were highest for leaves of huisache (45.3 mg CE/g DM) and lowest for mesquite (25.9 mg CE/g DM). Pods and leaves of huisache presented the highest number of secondary metabolites, mainly related to hydroxybenzoic acid and flavonols; leucaena and mesquite presented mainly flavonols and anthocyanins. It was concluded that leaves and pods of leucaena, mesquite, and huisache constitute valuable forages for ruminant livestock due to their low fiber, high $\mathrm{CP}$ levels, moderate in vitro fermentation characteristics and high mineral content.
\end{abstract}

Keywords: Fodder tree; Minerals; Ruminants; Secondary metabolites; Tannins

\section{INTRODUCTION}

Fluctuations in pasture availability in semi-arid and subtropical zones force goat producers to use foliage and fruits of various leguminous trees as supplementary feeds for improving nutrient supply to grazing livestock (Hove et al., 2001; Fasae et al., 2011), as foliage and fruits of these trees can contribute to maintain or improve production efficiency in ruminants (García et al., 2008; Rodríguez et al., 2009; Quiroz-Cardoso et al., 2015). Acacia farnesiana is particularly abundant in many countries and its foliage and fruits can be valuable for the contribution of energy and protein in the diet of small ruminants (García-Winder et al 2009; Garcia-Montes de Oca et al., 2011). Leucaena leucocephala is another high proteinaceous legume that is used as supplement for small ruminants ingesting poor quality feed (Harun et al., 2017). Likewise, foliage and pods of honey mesquite [Prosopis glandulosa (Torr.) glandulosa] is a potential foraging resource in semi-arid and subtropical rangelands (Harun et al., 2017; Mayagoitia et al., 2020).

These leguminous tree species are common in ecosystems around the world and their fruits (pods) are readily eaten by livestock (Kneuper et al., 2003; García-Winder et al., 2009) and have enough contents of crude protein (CP) and dry matter (DM) for facing the demands of small ruminants in harsh environments (Barrientos-Ramírez et al., 2012; Walker 2012). Therefore, the use of these leguminous trees as a forage resource in rangelands could increase the sustainability of livestock operations by providing high-quality forage during periods when herbaceous forage is limited or low in quality (GarciaMontes de Oca et al., 2011). Given that leguminous trees in semiarid and subtropical rangelands play an important role in maintaining year-long productivity of livestock (Maphosa et al., 2009; Pereira et al., 2013), there is a need to further investigate the advantages and disadvantages

\section{*Correspondence:}

Miguel Mellado, Autonomous Agrarian University Antonio Narro, Department of Animal Nutrition. E-mail: melladomiguel07@gmail.com

Received: 21 August 2020; $\quad$ Accepted: 30 October 2020 
of these arboreal legumes present in many countries for silvopastoral use with livestock.

It was considered important to deepen the chemical composition and nutritional value of three leguminous trees heavily selected by livestock. This experiment was thus conducted with three objectives: (a) to assess the nutrient composition and secondary compounds of foliage and pods from three leguminous trees heavily used by livestock, (b) to investigate the in vitro digestibility characteristics of these forage plants, and (c) to characterize the mineral content of three leguminous trees highly consumed by livestock.

\section{MATERIAL AND METHODS}

\section{Study area sampling of leaves and pods}

This study was conducted in a subtropical zone of northeastern Mexico (23 $44^{\prime} 06^{\prime \prime} \mathrm{N}$; $\left.99^{\circ} 07^{\prime} 51^{\prime \prime} \mathrm{W}\right)$ at an average altitude of 321 meters. The average annual temperature is $23.5^{\circ} \mathrm{C}$ and the average annual rainfall is $780 \mathrm{~mm}$ with a summer rainfall season. The vegetation corresponds to the Tamaulipan thorn scrub (xerophilous shrubland). The foliage and pods sampling was carried out from April to June 2017 (rainy season). The species sampled were leucaena, mesquite, and huisache (Fig. 1). The leaves and mature pods of 10 full-grown trees of each of these species were collected.

\section{Nutritional analysis}

Leaves and pods samples were dried in a forced-air oven at $50-60^{\circ} \mathrm{C}$ for $48 \mathrm{~h}$, to determine DM. Subsequently, they were ground to pass a 1-mm screen using a Wiley mill (Model 4; Arthur H. Thomas Co. Philadelphia, Pa., USA). Ash content was determined in duplicate by incineration in a muffle at $600^{\circ} \mathrm{C}$ for $2 \mathrm{~h}$; ether extract (EE) and PC, by the macro-Kjeldahl procedure (AOAC, 2000). Neutral detergent fiber (NDF), acid detergent fiber (ADF), lignin, hemicellulose, and cellulose was performed by the procedure described by Van Soest et al. (1991). The in vitro disappearance of the DM (IVDMD) was determined by the Tilley and Terry method modified by Barnes (1970). Concentration of calcium (Ca), magnesium $(\mathrm{Mg})$, potassium $(\mathrm{K})$, sodium $(\mathrm{Na})$, copper $(\mathrm{Cu})$, zinc $(\mathrm{Zn})$, manganese $(\mathrm{Mn})$, and iron $(\mathrm{Fe})$, was determined by atomic absorption spectrophotometry. Phosphorus (P) was measured by colorimetry using a spectrophotometer (model UV-2101 PC, Shimadzu Scientific Instruments, Columbia, MD) at $650 \mathrm{~nm}$ (AOAC, 2000).

\section{Metabolites extraction}

Aqueous extraction of three sub-samples $(10 \mathrm{~g} \mathrm{c} / \mathrm{u})$ from ground leaves and pods was carried out. For this procedure, the sample was weighed in $125 \mathrm{~mL}$ Erlenmeyer flasks, 100 $\mathrm{mL}$ of distilled water was poured at $60^{\circ} \mathrm{C}$ and was then homogenized. Afterward, it was placed inside a stove at $60^{\circ}$ C, stirring it every $15 \mathrm{~min}$ for $60 \mathrm{~min}$. It was then filtered through a Whatman No. 41 membrane. The material was centrifuged at $3000 \mathrm{rpm}$ for $10 \mathrm{~min}$. Finally, the aqueous extract was deposited in amber bottles and stored at $4^{\circ} \mathrm{C}$ until further processing.

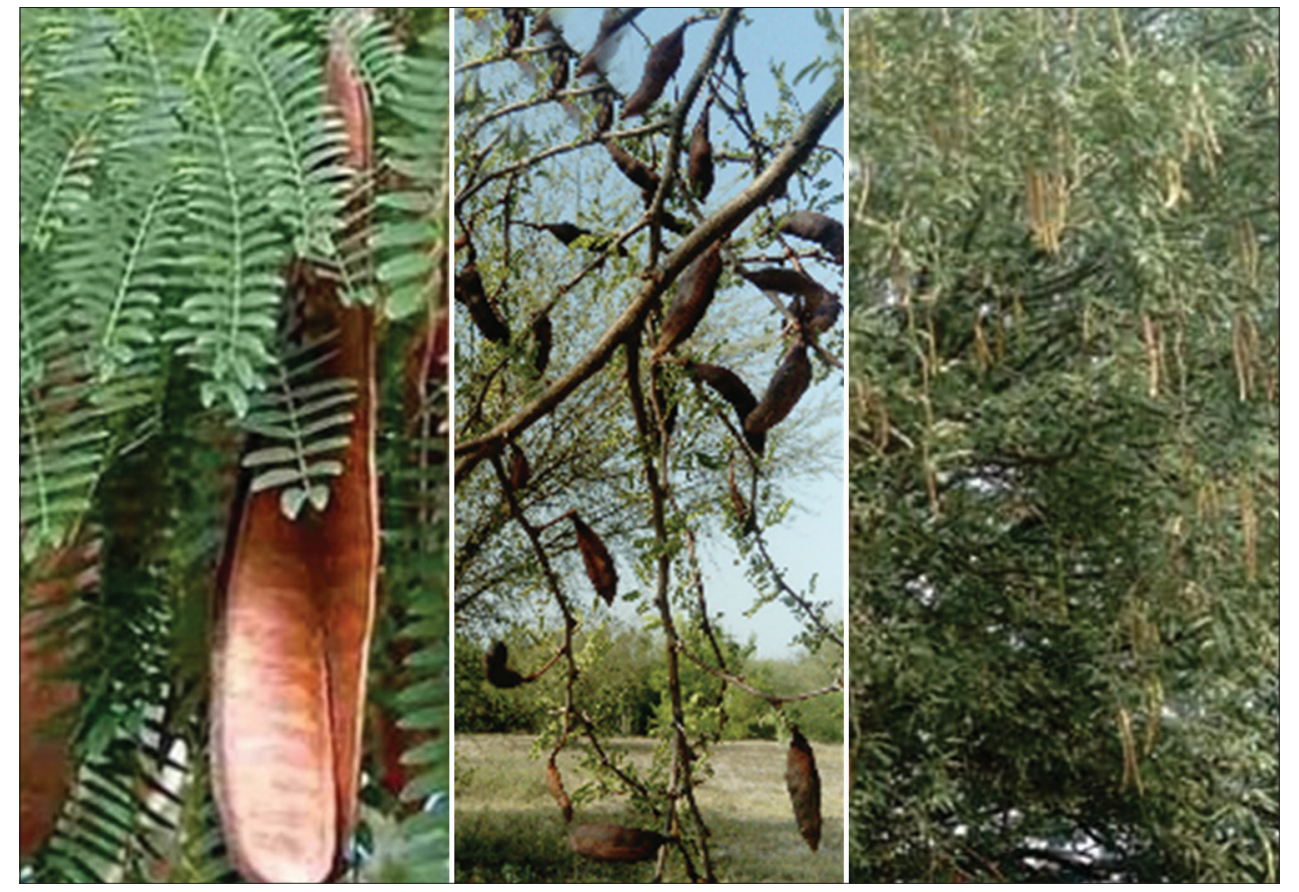

Fig 1. Foliage and pods of leguminous trees collected in northeastern Mexico and used in the study, (a) Leucaena leucocephala (Lam.) de Wit, (b) Acacia farnesiana (L.) Willd, (c) Prosopis laevigata (Humb. et Bonpl. ex Willd). 
Methanolic, acetonic, and ethanolic extraction were also carried out. One g of each sample was weighed and placed in a test tube to which $10 \mathrm{~mL}$ of each of these solutions $(70: 30 \mathrm{v} / \mathrm{v})$ were added. They were stirred in a vortex to homogenize them and were allowed to rest for $24 \mathrm{~h}$, avoiding exposure to light and were refrigerated at $4^{\circ} \mathrm{C}$. Subsequently, they were centrifuged at $3000 \mathrm{rpm}$ for $20 \mathrm{~min}$ and the supernatants were obtained for further analysis.

\section{Determination of condensed and hydrolyzable tannins}

The HCL-Butanol technique (Swain and Hillis, 1959) was used to obtain condensed tannins (CT). The reading of tubes with the extracts was carried out with a spectrophotometer with absorbance at $460 \mathrm{~nm}$. The concentration was calculated using the catechin as standard and the results were expressed as $\mathrm{mg} / \mathrm{g}$ in catechin equivalents (mg/CE/g DM). Hydrolyzable tannins (HT) were determined using the Folin Ciocalteu technique (Taga et al., 1984). The concentration was calculated using the gallic acid standard and the results were expressed as $\mathrm{mg}$ of gallic acid equivalent per $g$ of DM of the plant extract (mg/GAE/g DM).

\section{Partial purification of metabolites}

An aqueous extraction was carried out as previously described for leaves and pods of the trees for column chromatography (Still et al., 1978). The components of plants were detected with the ProStar Varian HPLC system (Spectra Lab Scientific Inc., Markham, Ontario Canada), with a three-phase pump, a model 410 autosampler, and a diode array UV-vis detector. The column used for the analysis was a Varian Pursuit XRs c18, $4.6 \mathrm{~mm}$ x $250 \mathrm{~mm}$, with a flow of $1 \mathrm{~mL} / \mathrm{min}$ and a volume injection of $10 \mu \mathrm{L}$ per sample. Details of this procedure were described by Ascacio-Valdés et al. (2013).

\section{Statistical analyses}

The effects of tree leaves, pods, and the leaves by pods interaction on nutrient content of forage, IVDMD, and condensed and hydrolyzable tannins were analyzed as a completely randomized design using the MIXED procedure of SAS (SAS Institute Inc., Cary, NC, USA). Individual tree samples were considered the experimental unit. The effects of tree species and the leave $\times$ pod interaction were considered to be fixed effects and individual foliage and pod samples were considered to be a random effect. Significant differences detected by ANOVA were further investigated using the PDIFF option of SAS comparing tree's leaves and pods.

\section{RESULTS}

\section{Nutrient content of trees}

The ash content of leaves of forage trees ranged from 6.7 to $8.7 \%$, which confirms that these plants are rich in minerals such as calcium. The ash content in leaves was higher $(p<0.05)$ in leucaena and lower in mesquite and huisache (Table 1). In mature pods, ash content did not differ for mesquite and huisache, while leucaena presented twice $(p<0.01)$ the ash content as the other trees. Leaves $\times$ pods interaction was significant $(p>0.01)$; the ash content was highest in leucaena pods, while pods of mesquite and huisache had the lowest values.

Huisache presented the highest $(p<0.01)$ EE value whereas mesquite and leucaena had similar but lower values. Pods showed lower EE values than leaves, being the highest for leucaena, and the lowest for mesquite $(p<0.01)$. There was a leaves by pods interaction $(\phi<0.01)$ for this nutrient. The high EE content of huisache leaves was not reflected in the pods of this fodder tree.

CP content of leaves of trees varied markedly between forage species. PC was similar for leucaena and mesquite with the lowest value $(p<0.01)$ for huisache. For pods, the highest PC value was for leucaena and the lowest for mesquite $(p<0.01)$. A significant interaction was found between leaves and pods for CP. Whereas CP levels were

Table 1: Nutrient content and in vitro dry matter digestibility of three fodder trees used by goats in a xerophilous shrubland

\begin{tabular}{|c|c|c|c|c|c|c|c|c|c|}
\hline \multirow[t]{2}{*}{ Variables (\%) } & \multicolumn{3}{|c|}{ Leaves (L) } & \multirow[t]{2}{*}{ SEM } & \multicolumn{3}{|c|}{ Mature pods (P) } & \multirow[t]{2}{*}{ SEM } & \multirow{2}{*}{$\begin{array}{c}\text { P-value } \\
\mathrm{L} \times \mathrm{P}\end{array}$} \\
\hline & Leucaena & Mesquite & Huisache & & Leucaena & Mesquite & Huisache & & \\
\hline Ash & $8.7^{\mathrm{a}}$ & $6.7^{b}$ & $7.3^{b}$ & 0.8 & $7.4^{\mathrm{a}}$ & $3.5^{\mathrm{b}}$ & $3.5^{\mathrm{b}}$ & 0.3 & 0.0002 \\
\hline Ether extract & $4.1^{\mathrm{a}}$ & $3.8^{a}$ & $6.5^{\mathrm{b}}$ & 0.5 & 2.1 & 1.7 & 1.9 & 0.3 & $<.0001$ \\
\hline Crude protein & $21.9^{a}$ & $21.2^{a}$ & $17.3^{b}$ & 1.3 & $22.1^{a}$ & $11.9^{b}$ & $17.2^{\mathrm{c}}$ & 1.1 & $<.0001$ \\
\hline NDF & 39.0 & 39.1 & 40.3 & 8.6 & $52.0^{a}$ & $39.4^{\mathrm{b}}$ & $24.6^{c}$ & 3.2 & $<.0001$ \\
\hline ADF & $19.9^{a}$ & $27.6^{b}$ & $22.8^{c}$ & 2.8 & $35.7^{a}$ & $30.3^{b}$ & $17.1^{\mathrm{c}}$ & 1.8 & $<.0001$ \\
\hline Hemicellulose & 19.1 & 11.4 & 17.4 & 9.3 & $16.2^{\mathrm{a}}$ & $16.0^{\mathrm{a}}$ & $7.5^{\mathrm{b}}$ & 3.1 & 0.22 \\
\hline Cellulose & $17.0^{\mathrm{a}}$ & $29.2^{b}$ & $28.4^{b}$ & 0.8 & $24.4^{\mathrm{a}}$ & $20.8^{b}$ & $13.4^{c}$ & 0.6 & $<.0001$ \\
\hline Lignin & $5.7^{\mathrm{a}}$ & $4.0^{\mathrm{a}}$ & $7.8^{\mathrm{b}}$ & 1.1 & $8.4^{a}$ & $4.9^{b}$ & $3.7^{b}$ & 1.0 & 0.0002 \\
\hline IVDMD & $54.9^{a}$ & $54.4^{a}$ & $47.3^{b}$ & 4.9 & $50.6^{a}$ & $65.7^{b}$ & $68.5^{b}$ & 5.1 & $<.0001$ \\
\hline
\end{tabular}

Leucaena (Leucaena leucocephala), mesquite (Prosopis laevigata), huisache (Acacia farnesiana).NDF= neutral detergent fiber; ADF=acid detergent fiber; IVDMD = in vitro dry matter disappearance. $S E M=$ standard error of the mean. $L \times P=$ Leaves $\times$ mature pods interaction. Within part of the plant, means bearing different superscript letters differ $(P<0.05)$ 
similar for leaves and pods in leucaena, no such similitude was found for CP between leaves and pods of the other trees.

For leaves, NDF did not differ among trees, but regarding pods, this fiber fraction was highest $(p<0.01)$ in leucaena and lowest in huisache. The highest value for ADF was found in leaves of mesquite and the lowest in leucaena. Regarding pods, leucaena had the highest value whereas huisache had the lowest value. For both NDF and ADF there was an interaction between leaves and pods. The mean NDF and ADF content of leaves of some fodder trees was lower than pods; the opposite occurred with other trees.

No differences were detected among trees for hemicellulose content of leaves, but hemicellulose in pods of huisache was lower $(p<0.01)$ than that in other trees. Cellulose levels in leaves of mesquite were 12 percentage points lower $(p<0.01)$ than the other trees. For huisache, the cellulose content of leaves was highest $(p<0.01)$ in mesquite and lowest for leucaena. Pods of leucaena presented the highest $(p<0.01)$ content of cellulose compared to the other fodder trees. There was a significant leaves $\times$ pods interaction for this cell wall component, basically because cellulose levels were higher in pods than leaves in leucaena; the opposite occurred with the other trees. Lignin content of leaves was highest $(p<0.01)$ for leucaena and lowest for mesquite. On the other hand, lignin content of pods of leucaena was about two times higher than that of the other trees. The mean IVDMD was lower $(p<0.05)$ for leaves of huisache, compared to leucaena and mesquite (Table 1). The opposite occurred with pods where huisache surpassed $(p<0.01)$ all other trees. Leaves $\times$ pods interaction was significant $(p<0.01)$ for IVDMD.

\section{Mineral content}

For both leaves and pods, no significant differences were found between fodder trees for $\mathrm{Ca}, \mathrm{P}, \mathrm{Mg}, \mathrm{Na}$, and $\mathrm{K}$ $(p>0.05$; Table 2). Cu concentration in leaves varied significantly among tree species $(p<0.05)$. As for pods, the levels of $\mathrm{Cu}$ in mesquite and huisache were two times higher $(p<0.05)$ than leucaena. Leaves $\times$ pods interaction was significant for this microelement $(p=0.05)$ because there was a marked difference in $\mathrm{Cu}$ content between leaves and pods for leucaena, but levels of this mineral did not differ between leaves and pods of mesquite and huisache. In leaves, Fe levels were greatest $(p<0.01)$ in huisache and lowest in leucaena. Considering pods, Fe levels were greatest $(p<0.01)$ in mesquite and lowest in leucaena. There was a significant leaves $\times$ pods interaction for this microelement. The difference between the manganese concentrations of leaves was different for fodder trees $(p<0.01)$. Also, zinc levels were highest $(p<0.01)$ in leaves of mesquite and lowest in huisache. There was a significant leaves $\times$ pods interaction for this microelement because levels of this mineral did not differ between leaves and pods of leucaena, but this mineral markedly changed between leaves and pods for the other trees.

\section{Hydrolyzable and condensed tannins}

Leaves of all tree species had HT contents lower than $1.5 \mathrm{mg}$ galic acid equivalent/g DM (acetonic extract; Table 3). Regardless of the extract used, mesquite had a lower $(p<0.01)$ HT content than that of leucaena and huisache. Regarding pods, huisache had the highest $(p<0.01)$ concentration of HT compared to leucaena and mesquite. Leaves of all leguminous trees had CT contents lower than $45 \mathrm{mg} / \mathrm{g}$ DM. With the acetonic extract, huisache leaves had the highest $(p<0.01)$ concentration of CT compared to mesquite that had the lowest (Table 3). The acetonic extract gave the highest concentration of CT in pods, with the highest $(p<0.01)$ concentration for leucaena and the lowest for mesquite.

\section{Secondary metabolites}

The HPLC system showed the presence of an important number of plant components. Gallic acid 4-O-glucoside and its isomer were found in leaves and pods of huisache belonging to the family of hydroxybenzoic acids (Table 4). Three-p-coumaroylquinic acid was isolated from leaves

Table 2: Mineral content of three fodder trees used by goats in xerophilous shrubland

\begin{tabular}{|c|c|c|c|c|c|c|c|c|c|}
\hline \multirow[t]{2}{*}{ Minerals } & \multicolumn{3}{|c|}{ Leaves (L) } & \multirow[t]{2}{*}{ SEM } & \multicolumn{3}{|c|}{ Mature pods (P) } & \multirow[t]{2}{*}{ SEM } & \multirow{2}{*}{$\begin{array}{c}\text { P-value } \\
L \times P\end{array}$} \\
\hline & Leucaena & Mesquite & Huisache & & Leucaena & Mesquite & Huisache & & \\
\hline Calcium, $\mathrm{g} / \mathrm{kg}$ & 6.2 & 6.8 & 5.4 & 1.7 & 8.0 & 4.3 & 5.3 & 3.3 & NS \\
\hline Phosphorus, g/kg & $1.5^{\mathrm{a}}$ & $3.0^{\mathrm{b}}$ & $1.6^{\mathrm{a}}$ & 0.4 & 1.9 & 2.5 & 1.2 & 1.1 & NS \\
\hline Magnesium, g/kg & 1.9 & 1.4 & 1.5 & 0.8 & 1.7 & 1.2 & 1.1 & 0.9 & NS \\
\hline Sodium, $\mathrm{g} / \mathrm{kg}$ & 1.0 & 1.3 & 1.4 & 0.2 & 1.8 & 2.3 & 1.2 & 1.0 & NS \\
\hline Potasium, g/kg & 5.5 & 23.3 & 4.9 & 9.5 & 11.4 & 7.3 & 4.8 & 5.0 & 0.07 \\
\hline Copper mg/kg & $7.2^{\mathrm{a}}$ & $10.0^{b}$ & $9.0^{\mathrm{ab}}$ & 1.1 & $3.8^{a}$ & $8.2^{\mathrm{b}}$ & $8.9^{b}$ & 1.0 & 0.05 \\
\hline Iron, mg/kg & $12.7^{\mathrm{a}}$ & $16.7^{b}$ & $22.7^{c}$ & 1.9 & $11.7^{\mathrm{a}}$ & $47.3^{b}$ & $40.3^{b}$ & 11.6 & 0.02 \\
\hline Mangan, $\mathrm{mg} / \mathrm{kg}$ & $44.0^{\mathrm{a}}$ & $31.0^{\mathrm{b}}$ & $25.7^{\mathrm{b}}$ & 4.7 & 18.3 & 14.7 & 13.0 & 3.9 & 0.06 \\
\hline Zinc, mg/kg & $58.0^{\mathrm{a}}$ & $79.7^{b}$ & $57.6^{\mathrm{a}}$ & 5.7 & 58.3 & 57.0 & 73.7 & 10.7 & 0.01 \\
\hline
\end{tabular}

Leucaena (Leucaena leucocephala), mesquite (Prosopis laevigata), huisache (Acacia farnesiana).NDF= neutral detergent fiber; $A D F=$ acid detergent fiber; IVDMD= in vitro dry matter disappearance. $S E M=$ standard error of the mean. $\mathrm{L} \times \mathrm{P}=\mathrm{L}$ eave $\times$ mature pods interaction. Within part of the plant, means bearing different superscript letters differ $(\mathrm{P}<0.05)$. 
of leucaena and mesquite, this compound belongs to the family of the hydroxycinnamic acids (Table 5). The compounds apigenin 6,8-di-C-glucoside belonging to the family of flavones and quercetin 3-O-rutinoside of the flavonols family were found only in leaves of huisache (Table 4). Cyanidin 3-O- (6 “-malonyl-3" -glucosylglucoside) from the family of the anthocyanins, was isolated from leaves of leucaena, mesquite, and huisache
(Table 4 and 5). Whereas isorhamnetin 3-O-glucoside 7-O-rhamnoside from the methoxyflavonols family was found only in leaves of huisache. p-HPEA-EDA, quercetin 3,4'-O-diglucoside, and quercetin 3-O-xylosyl-glucuronide were found in pods of mesquite (Table 5); procyanidin dimer B1 of the proanthocyanidin family was obtained from leaves of leucaena and mesquite (Table 5). Gallic acid 3-O-gallate and its isomer, patuletin 3-O-glucosyl-

Table 3: Hydrolysable and condensed tannins content of fodder trees selected by goats in a xerophilous shrubland

\begin{tabular}{|c|c|c|c|c|c|c|c|c|}
\hline \multirow[t]{2}{*}{ Extracts } & \multicolumn{3}{|c|}{ Leaves } & \multirow[t]{2}{*}{ SEM } & \multicolumn{3}{|c|}{ Mature pods } & \multirow[t]{2}{*}{ SEM } \\
\hline & Leucaena & Mesquite & Huisache & & Leucaena & Mesquite & Huisache & \\
\hline \multicolumn{9}{|c|}{ Hydrolyzable tannins (mg galic acid equivalent/g dry matter) } \\
\hline Aqueous & $1.14^{\mathrm{a}}$ & $0.22^{b}$ & $0.74^{c}$ & 0.03 & $0.51^{\mathrm{a}}$ & $0.07^{b}$ & $5.02^{\mathrm{c}}$ & 0.12 \\
\hline Metanolic & $1.09^{a}$ & $0.07^{\mathrm{b}}$ & $0.81^{\mathrm{a}}$ & 0.16 & $0.41^{\mathrm{a}}$ & $0.09^{a}$ & $4.35^{\mathrm{b}}$ & 0.82 \\
\hline Acetonic & $1.28^{\mathrm{a}}$ & $0.15^{b}$ & $1.42^{\mathrm{a}}$ & 0.15 & $1.28^{\mathrm{a}}$ & $0.20^{\mathrm{b}}$ & $3.88^{\mathrm{c}}$ & 0.25 \\
\hline Ethanolic & $0.59^{a}$ & $0.03^{b}$ & $0.72^{\mathrm{a}}$ & 0.10 & $0.07^{\mathrm{a}}$ & $0.13^{a}$ & $1.29^{b}$ & 0.06 \\
\hline \multicolumn{9}{|c|}{ Condensed tannins (mg catechin equivalent/g dry matter) } \\
\hline Aqueous & $19.44^{\mathrm{a}}$ & $20.55^{a}$ & $13.51^{\mathrm{b}}$ & 2.75 & $27.72^{\mathrm{a}}$ & $9.25^{b}$ & $12.83^{c}$ & 1.03 \\
\hline Metanolic & $28.83^{a}$ & $11.11^{\mathrm{b}}$ & $26.64^{\mathrm{a}}$ & 3.84 & 22.01 & 16.10 & 10.66 & 5.63 \\
\hline Acetonic & $37.01^{\mathrm{ab}}$ & $25.86^{a}$ & $45.28^{b}$ & 6.86 & $39.70^{a}$ & $14.36^{b}$ & $16.92^{b}$ & 4.55 \\
\hline Ethanolic & $21.70^{a}$ & $15.53^{b}$ & $20.62^{a}$ & 2.22 & 12.23 & 7.10 & 9.52 & 3.43 \\
\hline
\end{tabular}

Leucaena (Leucaena leucocephala), mesquite (Prosopis laevigata), huisache (Acacia farnesiana). SEM= standard error of the mean.Means bearing different superscript letters differ $(P<0.01)$

Table 4: Secondary metabolites identified in the aqueous extract of huisache (Acacia farnesiana).

\begin{tabular}{lcll}
\hline RT $(\mathrm{min})$ & {$[\mathrm{M}-\mathrm{H}]-\mathrm{m} / \mathbf{z}$} & Compound & Family \\
\hline Leaves & & & \\
3.59 & 330.8 & Gallic acid 4-O-glucoside & Hydroxybenzoic acids \\
4.34 & 336.6 & 3-p-Coumaroylquinic acid & Hydroxycinnamic acids \\
26.81 & 592.8 & Apigenin 6,8-di-C-glucoside & Flavones \\
32.73 & 608.7 & Quercetin 3-O-rutinoside & Flavonols \\
34.31 & 696.2 & Cyanidin 3-O-(6"-malonyl-3"-glucosyl-glucoside) & Anthocyanins \\
35.58 & 622.8 & Isorhamnetin 3-O-glucoside 7-O-rhamnoside & Methoxyflavonols \\
Pods & & & Hydroxybenzoic acids \\
4.21 & 331 & Gallic acid 4-O-glucoside & Hydroxybenzoic acids \\
9.78 & 331 & Gallic acid 4-O-glucoside (isomer) & Hydroxybenzoic acids \\
22.51 & 320.9 & Gallic acid 3-O-gallate & Hydroxybenzoic acids \\
23.35 & 320.9 & Gallic acid 3-O-gallate (isomer) & Flavonols \\
26.38 & 634.9 & Kaempferol 3-O-(6"-acetyl-galactoside) 7-O-rhamnoside & Flavonols \\
28.5 & 634.9 & Kaempferol 3-O-(6"-acetyl-galactoside) 7-O-rhamnoside (isomero) & Methoxyflavonols \\
31.82 & 786.8 & Patuletin 3-O-glucosyl-(1->6)-[apiosyl(1->2)]-glucoside & Dihydrochalcones \\
38.094 & 585 & 3-Hydroxyphloretin 2'-O-xylosyl-glucoside & \\
\hline
\end{tabular}

RT: retention time; $[\mathrm{M}-\mathrm{H}] \cdot \mathrm{m} / \mathrm{z}$ : mass/charge

Table 5: Secondary metabolites identified in the aqueous extract of leucaena (Leucaena leucocephala) and mesquite (Prosopis laevigata).

\begin{tabular}{|c|c|c|c|}
\hline RT (min) & {$[\mathrm{M}-\mathrm{H}]-\mathrm{m} / \mathrm{z}$} & Compound & Family \\
\hline \multicolumn{4}{|c|}{ Leucaena and mesquite leaves } \\
\hline 3.93 & 336.8 & 3-p-Coumaroylquinic acid & Hydroxycinnamic acids \\
\hline 32.76 & 696.2 & Cyanidin 3-O-(6"-malonyl-3"-glucosyl-glucoside) & Anthocyanins \\
\hline 34.79 & 576.3 & Procyanidin dimer B1 & Proanthocyanidin dimers \\
\hline \multicolumn{4}{|c|}{ Mesquite pods } \\
\hline 3.8 & 301.8 & p-HPEA-EDA & Tyrosols \\
\hline 28.8 & 624.8 & Quercetin 3,4'-O-diglucoside & Flavonols \\
\hline 31.7 & 608.8 & Quercetin 3-O-xylosyl-glucuronide & Flavonols \\
\hline
\end{tabular}

RT: retention time; [M-H]-m/z: mass/charge 
(1->6)-[apiosyl (1->2)]-glucoside and 3-hydroxyphloretin 2'-O-xylosyl-glucoside were found in pods of huisache. In general, the greatest number of secondary metabolites were found in huisache, both in leaves and in pods.

\section{DISCUSSION}

\section{Nutritient content}

Nutritionally, the fodder trees studied present outstanding characteristics for goats on rangeland. CP values of 24 to $33 \%$ have been found for leaves of leucaena (Lani et al., 2015; Santos et al., 2017). Although the above-mentioned values are higher than those found in this study $(21.8 \%)$, the percentage of $\mathrm{CP}$ of leucaena is adequate for feeding of goats in extensive systems, considering gestation and moderate milk yield (NRC, 2007). Regarding PC of pods of these fodder trees, only mesquite showed a low PC concentration $(11.9 \%)$ compared to $21.2 \%$ of leaves. For this tree, values of $16 \%$ have been reported in the rainy season and 12-13\% in the dry season (Mahgoub et al., 2005; Peña-Avelino et al., 2014).

Huisache presented the same PC content in both leaves and pods, this value is above the 9.4 to $13 \%$ reported by other researchers (Cuchillo et al., 2013; Quiroz-Cardoso et al., 2015; Rojas-Hernández et al., 2016). Besides, its high CP content, this tree is highly palatable by goats, constituting up to one-third of the grazing goat's diet (Mellado et al., 2004). Pods of this tree usually are inaccessible to grazing goats, therefore some goat herders in northern Mexico uses a machete to sieve them to make them available to goats while grazing. The PC content of the leucaena pod (22.1\%) was higher than that reported by Ortiz-Domínguez et al. (2017) of 19.2\% and lower than that found by (Ngwa et al., 2001) of $24.7 \%$.

Regarding NDF and ADF content in the foliage and pods of the trees studied, these levels are adequate to supplement other low-quality forages used by goats on rangeland, given that these levels of NDF and ADF do not limit feed intake through physical fill effects and by reducing the digestibility (Casler and Jung, 2006). In general, pods of leucaena showed the highest NDF and ADF content, which indicates that this fraction of the plant has more indigestible components that could affect its consumption by goats (Hove et al., 2001). In the present study, the fiber fraction content of leaves of leucaena was lower than pods; the opposite occurred with huisache, which resulted in a leaves $\times$ pods interaction for both NDF and ADF. These results are in line with other studies where the cell wall changes drastically between leaves and pods of leucaena (Walker, 2012) with no change between leaves and pods of this component in mesquite (Ali et al., 2012).
The lignin content in plants is one of the main limitations affecting the cell wall digestibility in ruminants (Krehbiel, 2014). In the trees analyzed, the lignin values were adequate, since the highest value was $8.4 \%$ for leucaena pods, a level that does not limit feed intake and DM digestibility (Moore and Jung, 2001; Harper and McNeill, 2015).

The IVDMD of the pods of mesquite and huisache (up to $68.5 \%$ ) was high. This was expected due to the low cell wall content in these leguminous trees. However, despite the relatively low levels of NDF and FDF in leaves of these trees, IVDMD was moderate, which is not in line with findings of Landa-Becerra et al. (2016), who found values of IVDMD for leaves of mesquite and huisache of $70 \%$ and $73 \%$, respectively, in the dry season in dry tropic conditions, but Ortiz-Domínguez et al. (2017) report a $46.38 \%$ digestibility for leucaena pods. It is known that DM digestibility is related to several factors such as NDF, ADF, CT, and lignin, the latter being the most important since it limits the microbial fermentation and enzymatic hydrolysis of cell wall polysaccharides (Moore and Jung, 2001).

Leaves of all fodder trees studied showed elevated content of $\mathrm{Ca}, \mathrm{K}, \mathrm{Zn}, \mathrm{Mn}$, and $\mathrm{Mg}$ and were within the range found in most tropical legumes (Abdulrazak et al., 2000; Rubanza et al., 2006). Except for $\mathrm{Cu}$ concentrations in pods of leucaena, all minerals found in these fodder trees did meet small ruminant requirements (Suttle, 2010).

\section{Secondary metabolites}

CT content was affected by tree species with the highest level in the pods of huisache but was higher with the acetonic extract than values reported by Ramana et al. (2000) for these trees. These levels of polyphenolic compounds are not involved in depressing DM intake in goats (Alonso-Díaz et al., 2008). Higher levels of polymerized CT (e.g., $>50 \mathrm{mg} / \mathrm{g} \mathrm{DM}$ ) impair utilization of CP from browse supplements by ruminants (Aerts et al., 1999).

Pods and leaves of huisache presented the highest number of secondary metabolites, mainly related to hydroxybenzoic acid and flavonols. Leucaena and mesquite presented flavonols and anthocyanins. The phenolic compounds and their efficiency as antiradicals and antioxidants are diverse. Rice-Evans et al. (1996) found that the antioxidant activity of gallic acid belonging to the family of hydroxybenzoic acids and found in pods and leaves of huisache, is usually higher than pyrogallol, demonstrating a significant influence of carboxylate on the antioxidant activity of the phenolic acids. Flavonols are flavonoids that protect the plant against herbivory by altering its palatability and reducing its digestibility (Mierziak et al., 2014). Hydroxycinnamic acid found in leaves of leucaena and mesquite has been related 
to antidiabetic, antioxidant, and anticancer properties (Petersen and Simmonds 2003, Taofiq et al., 2017).

\section{CONCLUSION}

Leaves and pods harvested from leucaena, mesquite and huisache constitute notable forage resources for goats on rangeland due to their outstanding crude protein and low fiber content. These leguminous trees would improve nutritional quality of a rangeland-based diet for goats. These fodder trees could also be used as potential sources of protein banks to supplement rangeland vegetation or the feeding of crop residues. The presence of condensed tannins and other secondary compounds does not seem to be a major constraint to their utilization by goats.

\section{ACKNOWLEDGMENT}

This work was supported by a grant from the Sectorial Fund SAGARPA-CONACYT (Mexico) (2017-4-291691).

\section{Author's contributions}

Conceived the experiment: C. Zapata-Campos, and M. Mellado. Performed chemical analysis: C. Zapata-Campos, J.A. Ascacio-Valdés, M.A. Medina-Morales. Performed statistical analysis and interpretation of results: J.E. GarcíaMartínez, J. Salinas-Chavira. Wrote the manuscript: M. Mellado. All authors read and approved the manuscript.

\section{REFERENCES}

Abdulrazak, S. A., E. A. Orden, T. Ichinohe and T. Fujihara. 2000. Chemical composition, phenolic concentration and in vitro gas production characteristics of selected acacia fruits and leaves. Asian-Australas. J. Anim. Sci. 13: 935-940.

Aerts, R. J., T. N. Barry and W. C. McNabb. 1999. Polyphenols and agriculture, beneficial effects of proanthocyanidins in forages, a review. Agric. Ecosyst. Environ. 75: 1-12.

Ali, A. S., S. Tudsri, S. Rungmekarat and K. Kaewtrakulpong. 2012. Effect of feeding Prosopis juliflora pods and leaves on performance and carcass characteristics of Afar sheep. Kasetsart J. Nat. Sci. 46: 871-881.

Alonso-Díaz, M. A., J. F. J. Torres-Acosta, C. A. Sandoval-Castro, H. Hoste, A. J. Aguilar-Caballero and C. M. Capetillo-Leal. 2008. Is goats' preference of forage trees affected by their tannin or fiber content when offered in cafeteria experiments? Anim. Feed Sci. Technol. 141: 36-48.

AOAC. 2000. Official Methods of Analysis. $15^{\text {th }}$ ed. AOAC, Washington, DC, USA.

Ascacio-Valdés, J., E. Burboa, A. F. Aguilera-Carbo, M. Aparicio, R. Pérez-Schmidt, R. Rodríguez and C. N. Aguilar. 2013. Antifungal ellagitannin isolated from Euphorbia antisyphilitica Zucc. Asian Pac. J. Trop. Biomed. 3: 41-46.

Barrientos-Ramírez, L., J. J. Vargas-Radillo, A. Rodríguez-Rivas, H. Ochoa-Ruíz, G. Navarro-Arzate and J. Zorrilla. 2012. Evaluation of characteristics of huizache Acacia farnesiana L.
Willd. fruit for potential use in leather tanning or animal feeding Madera Bosques. 18: 23-35.

Casler, M. D. and H. J. G. Jung. 2006. Relationships of fibre, lignin, and phenolics to in vitro fibre digestibility in three perennial grasses. Anim. Feed Sci. Technol. 125: 151-161.

Cuchillo, H., D. N. Puga, M. Wrage-Mönning, B. Espinosa, A. Montaño, R. Navarro-Ocaña, R. F. Pérez-Gil. 2013. Chemical composition, antioxidant activity and secondary metabolites of vegetation species ingested by goats on semiarid rangelands. J. Anim. Feed Sci. 22: 106-115.

Fasae, O. A., A. I. Adesope and V. O. A. Ojo. 2011. The effect of Leucaena leaf supplementation to maize residues on village goat performance. J. Anim. Plant Sci. 10: 1276-1282.

García, D. E., H. B. Wencomo, M. E. Gonzalez, M. G. Medina, L. J. Cova and I. Spengler. 2008. Evaluation of nineteen accessions of Leucaena leucocephala based in the nutritive quality of forage. Zoot. Trop. 26: 9-18.

Garcia-Montes de Oca, C. A., M. Gonzalez-Ronquillo, A. Z. M. Salem, J. Romero-Bernal, J. F. Pedraza and J. G. Estrada. 2011. Chemical composition and in vitro gas production of some legume browse species in subtropical areas of Mexico. Trop. Subtrop. Agroecosyst. 14: 589-595.

García-Winder, L. R., C. S. Goñi, L. P. A. Olguín, S. G. Díaz and J. C. M. Arriaga. 2009. Huizache Acacia farnesiana whole pods flesh and seeds as an alternative feed for sheep in Mexico. Trop. Anim. Health Prod. 41: 1615-1621.

Harper, K. J. and D. M. McNeill. 2015. The role of iNDF in the regulation of feed intake and the importance of its assessment in subtropical ruminant systems. Agriculture. 5: 778-790.

Harun, N. L. A., A. R. Alimon, M. F. Jahromi and A. A. Samsudin. 2017. Effects of feeding goats with Leucaena leucocephala and Manihot esculenta leaves supplemented diets on rumen fermentation profiles, urinary purine derivatives and rumen microbial population. J. Appl. Anim. Res. 45: 409-416.

Hove, L., J. H. Topps, S. Sibanda and L. R. Ndlovu. 2001. Nutrient intake and utilisation by goats fed dried leaves of the shrub legumes Acacia angustissima, Calliandra calothyrsus and Leucaena leucocephala as supplements to native pasture hay Anim. Feed Sci. Technol. 91: 95-106.

Kneuper, C. L., C. B. Scott and W. E. Pinchak. 2003. Consumption and dispersion of mesquite seeds by ruminants. J. Range Manage. 56: 255-259.

Krehbiel, C. R. 2014. Invited review, applied nutrition of ruminants, fermentation and digestive physiology. Prof. Anim. Sci. 30: 129-139.

Landa-Becerra, A. R., S. Mandujano, N. S. Martínez-Cruz and E. López. 2016. Analysis of the nutritional content of plants consumed by goats in a location in the cañada, Oaxaca. Trop. Subtrop. Agroecosyst. 19: 295-304.

Lani, M. L., L. Abdullah and R. Priyanto. 2015. Utilization of Leucaena leucocephala in traditional fattening program of Bali cattle in Amarasi. Media Petern. 38: 64-69.

Mahgoub, O., I. T. Kadim, N. E. Forsberg, D. S. Al-Ajmi, N. M. Al-Saqry, A. S. Al-Abri and K. Annamalai. 2005. Evaluation of meskit Prosopis juliflora pods as a feed for goats. Anim. Feed Sci. Technol. 121: 319-327.

Maphosa, V., J. L. N. Sikosana and V. Muchenje. 2009. Effect of doe milking and supplementation using Dichrostachys cinerea pods on kid and doe performance in grazing goats during the dry season. Trop. Anim. Health Prod. 41: 535-541.

Mayagoitia, P., D. W. Bailey and R. E. Estell. 2020. Phenological changes in the nutritive value of honey mesquite leaves, pods, and flowers in the Chihuahuan Desert. Agrosyst. Geosci 
Environ. 3: e20026.

Mellado, M., A. Olvera, J. Dueñez and A. Rodríguez. 2004. Effects of continuous or rotational grazing on goat diets in a desert rangeland. J. Appl. Anim. Res. 26: 93-100.

Mierziak, J., K. Kostyn and A. Kulma. 2014. Flavonoids as important molecules of plant interactions with the environment. Molecules. 19: $16240-16265$.

Moore, K. J. and H. J. G. Jung. 2001. Lignin and fiber digestion. J. Range Manag. 54: 420-430.

NRC. 2007. Nutrient reqUirements of Small Ruminants, Sheep, Goats, Cervids, and New World Camelids. National Academy Press, Washington, DC.

Ngwa, A. T., I. V. Nsahlai and M. L. K. Bonsi. 2001. The rumen digestion of dry matter, nitrogen and cell wall constituents of the pods of Leucaena leucocephala and some Acacia species. J. Sci. Food Agric. 82: 98-106.

Ortiz-Domínguez, G., J. Ventura-Cordero, P. González-Pech, J.FJ. Torres-Acosta, C.M. Capetillo-Leal and C.A. Sandoval-Castro. 2017. Nutritional value and in vitro digestibility of legume pods from seven trees species present in the tropical deciduous forest. Trop. Subtrop. Agroecosyst. 20: 505-510.

Peña-Avelino, L. Y., J. M. Pinos-Rodríguez, L. Yáñez-Estrada, B. I. Juárez-Flores, R. Mejia and H. Andrade-Zaldivar. 2014. Chemical composition and in vitro degradation of red and white mesquite Prosopis laevigata pods. South Afr. J. Anim. Sci. 46: 360-365.

Pereira, T. C. J., M. L. Albuquerque-Pereira, C. A. S. de Oliveira, L. S. Argôlo, C. A. S. Silva, M. S. Pedreira, P. J. P. Almeida and A. Santos. 2013. Mesquite pod meal in diets for lactating goats. Rev. Bras. Zoot. 42: 102-108.

Petersen, M. and M. S. J. Simmonds. 2003. Rosmarinic acid. Phytochem. 62: 121-125.

Quiroz-Cardoso, F., S. Rojas-Hernández, J. Olivares-Pérez, E. Hernández-Castro, R. Jiménez-Guillén, A. Córdova-Izquierdo, A. Villa-Mancera and S. Abdel-Fattah. 2015. Intake, nutritional composition and index relative palatability of fruits three acacias in feeding sheep and goats. Arch. Med. Vet. 47: 33-38.

Ramana, D. B. V., S. Singh, K. R. Solanki and A. S. Negi. 2000. Nutritive evaluation of some nitrogen and non-nitrogen fixing multipurpose tree species. Anim. Feed Sci. Technol. 88: 103-111.
Rice-Evans, C. A., N. J. Miller and G. Paganga. 1996. Structureantioxidant activity relationships of flavonoids and phenolic acids. Free Radic. Biol. Med. 20: 933-956.

Rodríguez, R., M. Fondevila and C. Castrillo. 2009. In vitro fermentation of Pennisetum purpureum CT-115 supplemented with four tropical browse legume species. Anim. Feed Sci. Technol. 151: 65-74.

Rojas-Hernández, S., J. Olivares-Pérez, F. Quiroz-Cardoso, A. VillaMancera, M. Salazar, Cipriano, L. M. C. Díaz and A. R. Palomar. 2016. Diagnosis of the palatability of fruits of three fodder trees in ruminants. Ecosist. Rec. Agropecu. 3: 121-127.

Rubanza, C. D. K., M. N. Shem, T. Ichinohe and T. Fujihara. 2006. Polyphenolics and minerals composition of selected browse tree species leaves native to North-Western Tanzania traditional fodder banks. J. Food Agric. Environ. 4: 328-332.

Santos, K. C., A. L. R. Magalhães, D. K. A. Silva, G. G. L. Araújo, G. M. Fagundes, N. G. Ybarra and A. L. Abdalla. 2017. Nutritional potential of forage species found in Brazilian semiarid region. Livest. Sci. 195: 118-124.

Still, W. C., M. Kahn and A. Mitra. 1978. Rapid chromatographic technique for preparative separations with moderate resolution. J. Org. Chem. 43: 2923-2925.

Suttle, N. F. 2010 Mineral Nutrition of Livestock. $4^{\text {th }}$ ed. CAB International, Oxfordshire, UK.

Swain, T. and W. E. Hillis. 1959. The phenolic constituents of Prunus domestica I. The quantitative analysis of phenolic constituents. J. Sci. Food Agric. 10: 63-68.

Taga, M., E. Miller, and D. Pratt. 1984. Chia seeds as a source of natural lipid antioxidants. J. Am. Oil Chem. Soc. 61: 928-931.

Taofiq, O., A. M. González-Paramás, M. F. Barreiro and I. C. F. Ferreira. 2017. Hydroxycinnamic acids and their derivatives: Cosmeceutical significance, challenges and future perspectives, a review. Molecules. 222: 281.

van Soest, P. J., J. B. Robertson and B. A. Lewis. 1991. Methods for dietary fiber, neutral detergent fiber, and nonstarch polysaccharides in relation to animal nutrition. J. Dairy Sci. 74: 3583-3597.

Walker, K. P. 2012. Fodder potential of leaves and pods of planted Leucaena diversifolia and $L$. leucocephala species in semi-arid Botswana. Int. Res. J. Agric. Sci. Soil Sci. 2: 445-450. 